\title{
Morphological Characteristics of Safflower Seedlings Under Compaction Levels in a Clayey Latosol
}

\author{
Pablo Chang ${ }^{1}$, Deonir Secco ${ }^{1}$, Aracéli Ciotti de Marins ${ }^{1}$, Luciene Kazue Tokura ${ }^{1}$, Ricielly Eloyze Rosseto ${ }^{1}$, \\ Simone Andreia Roehrs ${ }^{1}$, Claudia Borgmann ${ }^{1}$, Lilian Cristina de Souza Madalena ${ }^{1}$, Nayara F. F. da S. Cruz ${ }^{1}$, \\ Reginaldo Ferreira Santos ${ }^{1}$, Bruna de Villa ${ }^{1}$, Vitória Regina Morello Gongora ${ }^{2}$, Benhurt Gongora ${ }^{1}$, \\ Jair Antonio Cruz Siqueira ${ }^{1} \&$ Fernanda Nicole $Z^{2}{ }^{2}$ \\ ${ }^{1}$ Graduate Program, Master's in Engineering of Energy in Agriculture, State University of West Paraná, \\ Cascavel, Paraná, Brazil \\ ${ }^{2}$ Graduation in Agricultural Engineering, State University of West Paraná, Cascavel, Paraná, Brazil \\ Correspondence: Pablo Chang, Graduate Program, Master's in Engineering of Energy in Agriculture, State \\ University of West Paraná (UNIOESTE), Rua Universitária, 2069-Jardim Universitário, CEP: 85819-110, \\ Cascavel, Paraná, Brazil. Tel: 55-453-220-3151. E-mail: pablo-sdw@hotmail.com
}

Received: April 28, 2019

Accepted: June 7, 2019 Online Published: August 15, 2019

doi:10.5539/jas.v11n13p115

URL: https://doi.org/10.5539/jas.v11n13p115

\begin{abstract}
This study aimed to evaluate the effect of soil compaction levels on initial development of safflower genotypes (Carthamus tinctorius). The experimental design was $2 \times 2 \times 6$, composed of two sowing seasons (May and June 2017), two genotypes (IMA-2103 and IMA-4409) and six levels of soil density $(1.0,1.1,1.2,1.3,1.4$, and $1.5 \mathrm{~g}$ $\mathrm{cm}^{-3}$ ), with three replicates. After 30 days of planting, percentage of emergence, emergence speed index, mean time of emergence and mean speed of emergence were analyzed. Among the morphological characteristics, plant height, stem diameter, root length, shoot and root fresh mass, shoot dry mass and number of healthy and wilted leaves were evaluated. The compaction states did not significantly interfere in the emergence of the safflower seedlings that were sown in the uncompacted surface layer. As soil compaction increased, root length, shoot fresh mass, shoot dry mass and root fresh mass were reduced in both genotypes. Soil density considered critical to safflower root growth was $1.3 \mathrm{~g} \mathrm{~cm}^{-3}$. The IMA-4409 genotype, in relation to IMA-2103, was more tolerant to soil compaction levels.
\end{abstract}

Keywords: soil density, safflower, tolerance

\section{Introduction}

Safflower (Carthamus tinctorius) is one of the most important oilseeds in the world (Sharifi, Namvar, \& Sharifi, 2017). It belongs to the Asteraceae family and is an annual herbaceous diploid $(2 \mathrm{n}=24)$ crop that adapts to hot and dry climates, with the ability to survive on minimal surface moisture (Liu et al., 2016). The plant produces edible oil rich in unsaturated fatty acids, and has a high oil content of about 44\% (Ambreen et al., 2015).

It is considered an important medicinal plant (Soleymani, 2017), as its oil is currently used as a thermogenic compound, also used in the treatment of cardiovascular problems (Toma, 2014). Several studies have shown that dietary supplementation with safflower oil had a positive effect on the lipid profile, with an antiatherogenic function (Santana et al., 2017).

In addition to its usefulness as an edible oil, safflower oil is grown for energy purposes in the production of biodiesel, standing out as an economically feasible fuel alternative. Due to the depletion of biological resources of fossils, the search for substitutes of raw material for the production of biofuels has grown and the safflower is of great prominence (Bonfim-Silva, Paludo, J. V. R. Sousa, H. H. F. Sousa, \& Silva, 2015). Its advantage consists of its biodegradability and low emission of pollutants (Brás, Possenti, Bueno, Canova, \& Schammas, 2014). In Brazil, safflower can be developed in several regions of the country, since harvesting practices can be mechanized and do not need require specific machines for its cultivation, which becomes a relevant factor for its success (Martins et al., 2017). 
There is, however, a need to improve agricultural technology for increased safflower production (Sharifi et al., 2017). In Brazil, safflower is a poorly studied crop, so the research of its physical-chemical properties is of paramount importance for the progress of post-harvest grain stages (Martins et al., 2017).

Soil compaction status - described as the increase in soil density, resulting from the application of pressure or load and the soil moisture factor (Szumczak et al., 2014) — can be considered as one of the factors for the study. That occurs because, as soil density exceeds critical density values, it can happen in severe conditions restrictive to plants (Guimarães et al., 2013).

In the field of soil physics, the increase of compaction leads to a decrease in the volume of macropores, which reduces oxygen concentration, making it difficult to perform gas exchanges, reducing organic matter mineralization and, finally, lowering root development (Guimarães et al., 2013; Ortigara, Koppe, Luz, Kaiser, \& Silva, 2014; Sampietro, Lopes, \& Reichert, 2015).

In the studies of Ortigara et al. (2014), Barik et al. (2014), and Sampietro et al. (2015) presented results of increased resistance to root penetration when soil density values were increased. Barik et al. (2014), when investigating the effect of traffic operations in the field on the change of soil physical properties, observed that the penetration resistance increased by $43.3 \%$, compared to the field with traffic and without traffic. In research carried out by Sarto, Bassegio, Rosolem, and Sarto (2018), safflower showed to be tolerant to soil compaction. In addition, evidence has indicated that it is a species with potential to decrease soil density.

Thus, in order to generate information on soil physical conditions to be considered critical for the development of this new crop, there is a justification for the execution of studies that submit the crop to growing compaction conditions while comparing these compaction conditions with the initial morphological characteristics of the crop.

The purpose of this study was to evaluate the effect of compaction levels on the morphological alterations of two varieties of safflower seedlings. This information is expected to provide a better understanding of the behavior of the species under compaction states, in order to induce new soil management techniques that improve the growing of this energy crop.

\section{Material and Method}

The experiment was conducted in the municipality of Toledo, state of Paraná, Brazil, from May to July 2017, under two planting seasons in a typical dystroferric Red Latosol (EMBRAPA, 2013). Figure 1 shows the representation of the climatic conditions of the city in the studied period. The data are obtained by the Paraná Meteorological System (SIMEPAR).

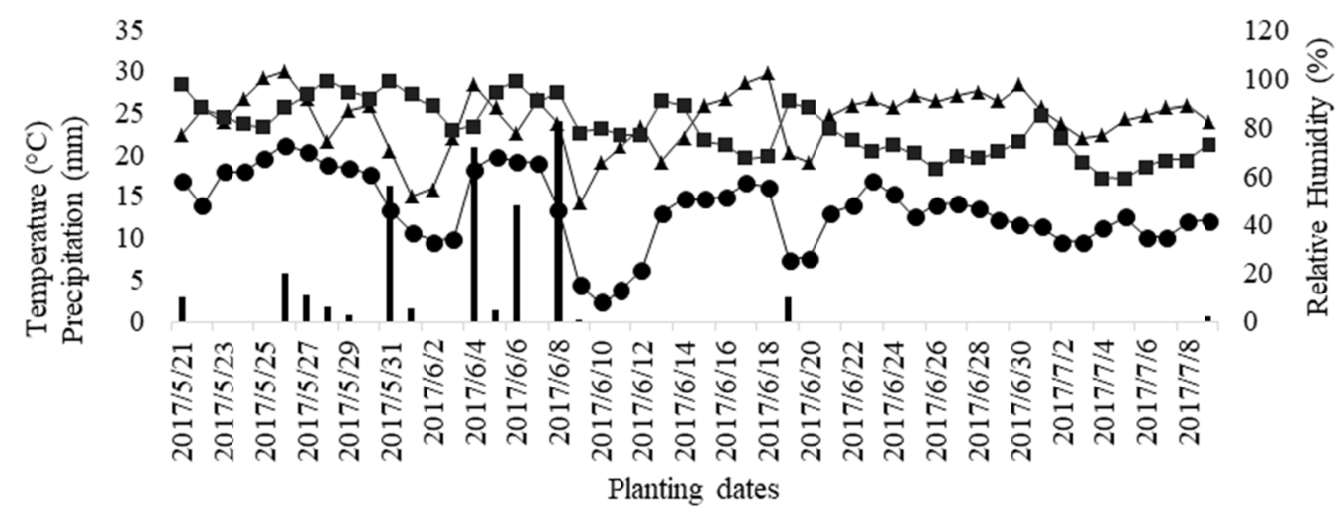

Precipitation $\longrightarrow$ Maximum temperature - - Minimum temperature $\rightarrow-$ Relative humidity

Figure 1. Precipitation, maximum and minimum temperature and relative humidity during the safflower evaluation period

Two varieties of Carthamus tinctorius seeds-genotypes IMA-2103 and IMA-4409-were used. Information on soil chemical characteristics, including macronutrients and micronutrients, is presented in Table 1. 
Table 1. Chemical characterization of the soil used

\begin{tabular}{|c|c|c|c|c|c|c|c|c|c|c|c|c|}
\hline $\mathrm{pH}\left(\mathrm{CaCl}_{2}\right)$ & Mehlich 1 phosphorus & $\mathrm{V}$ & $\mathrm{H}+\mathrm{Al}$ & $\mathrm{Ca}^{2+}$ & $\mathrm{Mg}^{2+}$ & $\mathrm{K}^{+}$ & $\mathrm{Na}^{+}$ & $\mathrm{Cu}^{2+}$ & $\mathrm{Fe}^{2+}$ & $\mathrm{Mn}^{2+}$ & $\mathrm{Zn}^{2+}$ & CTC \\
\hline & $\mathrm{mg} \mathrm{dm}^{-3}$ & $\%$ & - & ----- & - & 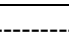 & $-\mathrm{cm}$ & $1_{\mathrm{c}} \mathrm{dm}^{-3}$ & 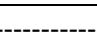 & . & 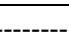 & -------- \\
\hline 5.76 & 14.37 & 85.36 & 2.19 & 8.18 & 4.31 & 0.23 & 0.05 & 7.02 & 335.53 & 221.80 & 2.33 & 14.96 \\
\hline
\end{tabular}

For the installation of the experiment, polyvinyl chloride (PVC) tubes with $0.2 \mathrm{~m}$ in height and $0.1 \mathrm{~m}$ in diameter were made. From the depths of $0-5 \mathrm{~cm}$ and $5-10 \mathrm{~cm}$, vertical surfaces were cut with a hand saw blade to form three rings of the same tube, representing a unit. For the fitting of the rings, adhesive tape was used.

The 5-10 $\mathrm{cm}$ layer of the tube was designated for compacted soil allocation, while the other layers were filled with soil without external pressure. For this, the calculations were made to find the values of the soil mass, necessary to represent the desired densities, namely 1.0, 1.1, 1.2, 1.3, 1.4 and $1.5 \mathrm{~g} \mathrm{~cm}^{-3}$ by means of the following equation.

$$
\mathrm{Ds}=\frac{\mathrm{DSM}}{\mathrm{TV}} \Rightarrow \mathrm{DSM}=\mathrm{Ds} \cdot \mathrm{TV}
$$

Where: Ds is the soil density, DSM is the dry soil mass and TV is the total volume of the ring. The wet soil mass (WSM) was previously weighed in a semi-analytical balance $( \pm 0.01 \mathrm{~g})$ to calculate soil moisture (M), represented by Equation 2.

$$
\mathrm{M}=\frac{\mathrm{WSM}-\mathrm{DSM}}{\mathrm{DSM}}
$$

Thus, the soil mass was calculated as a function of the desired density (MSd), adding the dry soil mass to the water mass calculated from the soil moisture percentage, according to Equation 3.

$$
\mathrm{MSd}=\mathrm{DSM} \cdot(\mathrm{M}+1) \Rightarrow \mathrm{MSd}=\mathrm{Ds} \cdot \mathrm{TV} \cdot(\mathrm{M}+1)
$$

The values of the masses used for the experiment are presented in Table 2. The soil samples were taken to the Soil Physics Laboratory (LAFIS) of the State University of Western Paraná, Cascavel Campus. The samples were then weighed and identified for each replicate and treatment in sealed plastic bags. The materials were then taken back for compacting in the PVC tubes only in the $0-5 \mathrm{~cm}$ layer, compressing each soil sample by means of a hammer and water. After the process, for each repetition the three rings were embedded and 5 seeds of

\begin{tabular}{|c|c|c|c|c|c|c|c|}
\hline \multirow{2}{*}{$\mathrm{TV}\left(\mathrm{cm}^{3}\right)$} & \multirow{2}{*}{ M (\%) } & \multicolumn{6}{|c|}{ Densities $\left(\mathrm{Mg} \mathrm{m}^{-3}\right)$} \\
\hline & & 1.0 & 1.1 & 1.2 & 1.3 & 1.4 & 1.5 \\
\hline \multirow{2}{*}{392.70} & $27.54 *$ & 500.86 & 550.94 & 601.03 & 651.12 & 701.21 & 751.29 \\
\hline & $24.49^{* *}$ & 488.89 & 537.78 & 586.67 & 635.55 & 684.44 & 733.33 \\
\hline
\end{tabular}
Carthamus tinctorius were sown at a depth of $2 \mathrm{~cm}$ from the soil surface.

Table 2. Soil mass values, in grams, used as a function of densities (MSd)

Note. * Soil moisture from the first planting season. ** Soil moisture from the second planting season. TV $=$ volume of the cylinder with $5 \mathrm{~cm}$ in height and $10 \mathrm{~cm}$ in diameter, where the soil mass of the respective treatments were compacted.

The experimental design consisted of a factorial arrangement $(2 \times 2 \times 6)$ with three replicates: two planting seasons (PS), the first one (PS I) sown on 5/21/17 and the second one (PS II) sown on 6/9/17; two safflower genotypes (IMA-2103 and IMA-4409) and 6 compaction levels $\left(1.0,1.1,1.2,1.3,1.4\right.$ and $1.5 \mathrm{Mg} \mathrm{m}^{-3}$ ). Seedlings were watered in the same amount of water every two days, except on days when precipitation occurred.

After 30 days of sowing, the percentage of emergence (PE), the emergence speed index (ESI), mean time of emergence (MTE) and mean emergence speed (MES) were evaluated. Among morphological analyses, plant height (PH), root length (RL), stem diameter (STEM), shoot fresh mass (SFM), shoot dry weight (SDW), root fresh mass (RFM), and number of healthy leaves (NHL) and withered leaves (NWL).

The percentage of emergence (Equation 4) is defined by the number of emerged seeds (ES) multiplied by 100 and divided by the total number of seeds (TS). The emergence speed index (Equation 5) was proposed by Maguire (1962) and is calculated by dividing the sum of the results of the relationship between the number of normal seedlings counted $\left(E_{n}\right)$ and the number of sowing days $\left(N_{n}\right)$. 
The mean time of emergence (Equation 6) according Labouriau and Valadares (1976) is expressed in days and divides the sum of the emerged seeds number in the interval between each count $\left(G_{n}\right)$ multiplied by the time elapsed between the onset of germination and the nth-count $\left(t_{n}\right)$ for the sum of the elapsed time. Finally, the mean speed of emergence (Equation 7) was calculated by the inverse of the mean time of emergence ( $t$ ), also expressed in days.

$$
\begin{gathered}
\mathrm{PE}=\frac{\mathrm{ES}}{\mathrm{TS}} \times 100 \\
\mathrm{ESI}=\sum_{\mathrm{n}=1}^{\mathrm{n}} \frac{\mathrm{E}_{\mathrm{n}}}{\mathrm{N}_{\mathrm{n}}} \\
\mathrm{MTE}=\frac{\sum_{\mathrm{i}=1}^{\mathrm{n}} \mathrm{g}_{\mathrm{n}} \mathrm{t}_{\mathrm{n}}}{\sum_{\mathrm{i}=1}^{\mathrm{n}} \mathrm{g}_{\mathrm{n}}} \\
\mathrm{MES}=\frac{1}{\mathrm{t}}
\end{gathered}
$$

The shoot fresh and dry masses and root fresh masses were weighed by means of an MAR analytical balance, AY220 model $( \pm 0.1 \mathrm{mg})$. For sterilization and drying of the of the plants, an Ethik greenhouse, 400-TD model $\left( \pm 0.1^{\circ} \mathrm{C}\right)$. To measure plant height, a measuring tape was used, while the stem diameter was measured using a digital caliper $( \pm 0.01 \mathrm{~mm})$.

Statistical analysis was performed by analysis of variance (ANOVA), and the mean values of the treatments were compared by Tukey test at 5\% significance with the aid of the R statistical software (R Core Team, 2014).

\section{Results and Discussion}

In the examination the analysis of variance regarding the emergence of the plants (Table 3), the emergency speed index and the mean time of emergence showed an interaction between planting season, genotype, and density. The mean values of the emergence percentage ranged from $70.90 \%$ to $81.82 \%$, indicating a high germination performance of the seedlings.

The mean time of emergence ranged from 1.54 to 2.11 days. The speed varied from 0.577 to 0.714 per day. The speed indices were relatively low compared to the study of Venturoso et al. (2015), who found that the transmission of Sclerotinia sclerotiorum on safflower and some energy crops, with $7.0 \mathrm{~d}^{-1}$ for the safflower ESI without inoculation and $1.9 \mathrm{~d}^{-1}$ for the inoculated crop. 
Table 3. Mean values of percentage of emergence (PE), emergence speed index (ESI), mean time of emergence (MTE), mean emergence speed (MES), number of healthy leaves (NHL) and number of withered leaves (NWL) by means of the factors density, genotype and planting season

\begin{tabular}{|c|c|c|c|c|c|c|}
\hline & PE (\%) & ESI (seeds per day) & MTE (d) & $\operatorname{MES}\left(\mathrm{d}^{-1}\right)$ & NHL & NWL \\
\hline PS & ns & $* * *$ & $\mathrm{~ns}$ & ns & $* * *$ & $* * *$ \\
\hline GEN & ns & ns & ns & ns & $*$ & $*$ \\
\hline Ds & ns & ns & ns & ns & ns & ns \\
\hline $\mathrm{PS} \times \mathrm{GEN}$ & ns & ns & ns & ns & ns & ns \\
\hline $\mathrm{PS} \times \mathrm{Ds}$ & $* *$ & $* * *$ & ns & ns & $* *$ & ns \\
\hline $\mathrm{GEN} \times \mathrm{Ds}$ & ns & ns & ns & ns & ns & ns \\
\hline $\mathrm{PS} \times \mathrm{GEN} \times \mathrm{Ds}$ & ns & ns & $* *$ & $* *$ & ns & ns \\
\hline $\mathrm{CV}(\%)$ & 23.99 & 23.77 & 36.81 & 30.00 & 18.03 & 58.55 \\
\hline \multicolumn{7}{|l|}{ Density $\left(\mathrm{g} \mathrm{cm}^{-3}\right)$} \\
\hline 1.0 & 73.333 & 0.571 & 1.551 & 0.714 & $5.542 \mathrm{a}$ & 1.250 \\
\hline 1.1 & 70.901 & 0.516 & 1.671 & 0.639 & $5.318 \mathrm{ab}$ & 1.318 \\
\hline 1.2 & 76.364 & 0.530 & 2.117 & 0.577 & $5.125 \mathrm{ab}$ & 1.333 \\
\hline 1.3 & 75.000 & 0.593 & 1.610 & 0.685 & $4.958 \mathrm{ab}$ & 1.208 \\
\hline 1.4 & 73.333 & 0.540 & 1.961 & 0.587 & $5.000 \mathrm{ab}$ & 1.417 \\
\hline 1.5 & 81.818 & 0.595 & 1.547 & 0.688 & $4.682 \mathrm{~b}$ & 1.182 \\
\hline DMS & 22.376 & 0.165 & 0.796 & 0.242 & 0.782 & 0.639 \\
\hline \multicolumn{7}{|l|}{ Genotype } \\
\hline IMA-2103 & 72.121 & 0.541 & 1.723 & 0.675 & $4.927 \mathrm{a}$ & $1.406 \mathrm{a}$ \\
\hline IMA-4409 & 77.778 & 0.573 & 1.803 & 0.618 & $5.282 \mathrm{~b}$ & $1.169 \mathrm{~b}$ \\
\hline LSD & 8.743 & 0.064 & 0.311 & 0.094 & 0.308 & 0.252 \\
\hline \multicolumn{7}{|l|}{ PS } \\
\hline I & 77.778 & $0.670 \mathrm{a}$ & 1.723 & 0.675 & $4.557 \mathrm{a}$ & $1.928 \mathrm{a}$ \\
\hline II & 72.121 & $0.456 \mathrm{~b}$ & 1.803 & 0.618 & $5.657 \mathrm{~b}$ & $0.643 \mathrm{~b}$ \\
\hline DMS & 8.743 & 0.064 & 0.311 & 0.094 & 0.308 & 0.252 \\
\hline
\end{tabular}

Note. $\mathrm{CV}=$ Coefficient of variation; LSD $=$ Least Significant Difference; $\mathrm{ns}=$ not significant; $*$ significant at $5 \%$; $* *$ significant at $1 \%$; *** significant at $0.1 \%$. Equal letters in the column represent equal means by the Tukey test at $5 \%$ of significance.

The amount of healthy and wilted leaves per plant showed an interference between the genotypes, and IMA-4409 presented the highest mean number of healthy leaves and the lowest mean number of wilted leaves, indicating good foliar performance.

In general, it was observed that compaction states did not significantly interfere with the emergence of Carthamus plants $(p>0.05)$. This can be clarified by the sowing condition itself, in which the first layer of $0-5$ $\mathrm{cm}$ of the PVC pipes, where they were sown at a depth of $2 \mathrm{~cm}$, did not have compacted soil. In turn, only the 5-10 cm layer underwent compaction treatments.

In the study of Zuo et al. (2017), when investigating the effects of sowing depth and soil compaction on the growth of Brassica napus L. seedlings, the emergence index was significantly improved with increasing sowing depth and without compaction, although it was drastically reduced in compacted soils. As with compaction, the emergence index increased in shallow seeding, while there was no significant effect in deep sowing. 
Table 4. Density factor breakdowns within planting season (PS) and genotype (GEN) levels for each mean percentage of emergence (PE), plant height (PH), root length (RL), plant fresh mass (SFM) and root fresh mass (RFM) according to each experiment and genotype for a given density

\begin{tabular}{|c|c|c|c|c|c|c|c|}
\hline & \multirow{2}{*}{ PS } & \multicolumn{6}{|c|}{ Densities $\left(\mathrm{g} \mathrm{cm}^{-3}\right)$} \\
\hline & & 1.0 & 1.1 & 1.2 & 1.3 & 1.4 & 1.5 \\
\hline \multirow{2}{*}{ PE $(\%)$} & $\mathrm{I}$ & $80.00 \mathrm{aA}$ & $48.00 \mathrm{aA}$ & $68.00 \mathrm{aA}$ & $80.00 \mathrm{aA}$ & $46.67 \mathrm{aA}$ & $76.00 \mathrm{aA}$ \\
\hline & II & $66.67 \mathrm{aA}$ & $90.00 \mathrm{bA}$ & $83.33 \mathrm{aA}$ & $70.00 \mathrm{aA}$ & $70.00 \mathrm{aA}$ & $86.67 \mathrm{aA}$ \\
\hline \multirow{2}{*}{ ESI (seeds per day) } & I & $0.74 \mathrm{aA}$ & $0.44 \mathrm{aB}$ & $0.58 \mathrm{aAB}$ & $0.79 \mathrm{aA}$ & $0.70 \mathrm{aA}$ & $0.71 \mathrm{aA}$ \\
\hline & II & $0.40 \mathrm{bA}$ & $0.58 \mathrm{aA}$ & $0.49 \mathrm{aA}$ & $0.39 \mathrm{bA}$ & $0.38 \mathrm{bA}$ & $0.49 \mathrm{bA}$ \\
\hline \multirow{2}{*}{ NHL } & I & $5.58 \mathrm{aA}$ & $4.60 \mathrm{aAB}$ & $4.50 \mathrm{aB}$ & $3.92 \mathrm{aB}$ & $4.42 \mathrm{aB}$ & $4.33 \mathrm{aB}$ \\
\hline & II & $5.50 \mathrm{aA}$ & $5.92 \mathrm{bA}$ & $5.75 \mathrm{bA}$ & $6.00 \mathrm{bA}$ & $5.58 \mathrm{bA}$ & $5.10 \mathrm{aA}$ \\
\hline \multirow{2}{*}{$\mathrm{PH}(\mathrm{cm})$} & I & $7.85 \mathrm{aAB}$ & $8.65 \mathrm{aA}$ & $7.79 \mathrm{aAB}$ & $6.61 \mathrm{aB}$ & $8.83 \mathrm{aA}$ & $8.11 \mathrm{aA}$ \\
\hline & II & $8.04 \mathrm{aAB}$ & $8.35 \mathrm{aA}$ & $8.32 \mathrm{aA}$ & $7.08 \mathrm{aAB}$ & $7.58 \mathrm{bAB}$ & $6.65 \mathrm{bB}$ \\
\hline \multirow{2}{*}{ COMP (cm) } & I & $17.39 \mathrm{aA}$ & $10.90 \mathrm{aB}$ & $12.96 \mathrm{aAB}$ & $12.50 \mathrm{aAB}$ & $8.43 \mathrm{aB}$ & $9.85 \mathrm{aB}$ \\
\hline & II & $17.46 \mathrm{aAB}$ & $21.42 \mathrm{bA}$ & $14.80 \mathrm{aB}$ & $13.75 \mathrm{aB}$ & $14.34 \mathrm{bB}$ & $12.75 \mathrm{aB}$ \\
\hline \multirow{2}{*}{ SFM (g) } & I & $0.76 \mathrm{aA}$ & $0.70 \mathrm{aAB}$ & $0.65 \mathrm{aAB}$ & $0.31 \mathrm{aC}$ & $0.65 \mathrm{aAB}$ & $0.48 \mathrm{aBC}$ \\
\hline & II & $0.58 \mathrm{bAB}$ & $0.56 \mathrm{aAB}$ & $0.63 \mathrm{aA}$ & $0.50 \mathrm{bAB}$ & $0.39 \mathrm{bAB}$ & $0.33 \mathrm{aB}$ \\
\hline \multirow{4}{*}{ RFM (g) } & I & $0.13 \mathrm{aA}$ & $0.11 \mathrm{aA}$ & $0.08 \mathrm{aA}$ & $0.06 \mathrm{aA}$ & $0.11 \mathrm{aA}$ & $0.09 \mathrm{aA}$ \\
\hline & II & $0.15 \mathrm{aAB}$ & $0.20 \mathrm{bA}$ & $0.15 \mathrm{bAB}$ & $0.15 \mathrm{bAB}$ & $0.12 \mathrm{aBC}$ & $0.07 \mathrm{aC}$ \\
\hline & GFN & \multicolumn{6}{|c|}{ Densities $\left(\mathrm{g} \mathrm{cm}^{-3}\right)$} \\
\hline & UEIV & 1.0 & 1.1 & 1.2 & 1.3 & 1.4 & 1.5 \\
\hline \multirow{2}{*}{$\mathrm{RL}(\mathrm{cm})$} & IMA-2103 & $15.64 \mathrm{aA}$ & $14.80 \mathrm{aAB}$ & $9.96 \mathrm{aBC}$ & $8.13 \mathrm{aC}$ & $11.54 \mathrm{aABC}$ & $7.41 \mathrm{aC}$ \\
\hline & IMA-4409 & $19.21 \mathrm{aA}$ & $18.17 \mathrm{aA}$ & $17.80 \mathrm{bA}$ & $18.13 \mathrm{bA}$ & $11.23 \mathrm{aB}$ & $14.94 \mathrm{bAC}$ \\
\hline
\end{tabular}

Note. $\mathrm{CV}=$ Coefficient of Variation; LSD $=$ Least Significant Difference; ns $=$ not significant; $*$ significant at 5\%; $* *$ significant at $1 \%$; *** significant at $0.1 \%$. Equal letters in the column represent equal means by the Tukey test at $5 \%$ of significance.

For the density factor (Table 5), significant differences were observed $(p>0.001)$ at plant height, root length, stem diameter, plant fresh mass, plant dry mass and root fresh mass. In the study of Fagundes, Silva, and Bonfim-Silva (2014), which evaluated the initial development of three sugarcane varieties at five levels of soil density, a significant interaction was observed between density with number of stalk, leaf area, stalk length, stalk dry mass and leaf dry mass. Similarly, as occurred in the study of Guimarães et al. (2013), where compaction levels changed significantly at millet height and shoot fresh and dry mass. The only ones that showed a significant difference $(\mathrm{p}>0.05)$ among the genotypes were root length, stem diameter, plant fresh mass, and root fresh mass. 
Table 5. Plant height (PH), root length (RL), stem diameter (STEM), plant fresh mass (SFM), plant dry mass (SDM) and root fresh mass (RFM) according to the density, genotype, and planting season (PS)

\begin{tabular}{|c|c|c|c|c|c|c|}
\hline & RH $(\mathrm{cm})$ & $\mathrm{RL}(\mathrm{cm})$ & STEM (mm) & SFM (g) & SDM (g) & RFM (g) \\
\hline EPP & Ns & $* * *$ & $* * *$ & ns & $* *$ & $* * *$ \\
\hline GEN & Ns & $* * *$ & $* *$ & $* * *$ & ns & $* * *$ \\
\hline Ds & $* * *$ & $* * *$ & $* * *$ & $* * *$ & $* * *$ & $* * *$ \\
\hline $\mathrm{PS} \times \mathrm{GEN}$ & ns & ns & ns & $\mathrm{ns}$ & $\mathrm{ns}$ & $* * *$ \\
\hline $\mathrm{PS} \times \mathrm{Ds}$ & $*$ & $* * *$ & ns & $* * *$ & ns & $* *$ \\
\hline $\mathrm{GEN} \times \mathrm{Ds}$ & ns & $* *$ & ns & ns & ns & ns \\
\hline $\mathrm{PS} \times \mathrm{GEN} \times \mathrm{Ds}$ & $\mathrm{ns}$ & $*$ & ns & $* *$ & $*$ & $* * *$ \\
\hline $\mathrm{CV}(\%)$ & 15.05 & 31.97 & 13.81 & 36.96 & 44.53 & 46.21 \\
\hline \multicolumn{7}{|l|}{ Density $\left(\mathrm{g} \mathrm{cm}^{-3}\right)$} \\
\hline 1.0 & $7.946 \mathrm{ab}$ & $17.425 \mathrm{a}$ & $2.350 \mathrm{a}$ & $0.673 \mathrm{a}$ & $0.103 \mathrm{a}$ & $0.142 \mathrm{ab}$ \\
\hline 1.1 & $8.486 \mathrm{a}$ & $16.636 \mathrm{ab}$ & $2.330 \mathrm{a}$ & $0.624 \mathrm{a}$ & $0.102 \mathrm{a}$ & $0.160 \mathrm{a}$ \\
\hline 1.2 & $8.054 \mathrm{a}$ & $13.879 \mathrm{abc}$ & $2.234 \mathrm{a}$ & $0.574 \mathrm{ab}$ & $0.102 \mathrm{a}$ & $0.115 a b c$ \\
\hline 1.3 & $6.846 \mathrm{~b}$ & $13.125 \mathrm{bc}$ & $1.962 \mathrm{~b}$ & $0.408 \mathrm{~b}$ & $0.063 \mathrm{~b}$ & $0.106 \mathrm{bc}$ \\
\hline 1.4 & $8.208 \mathrm{a}$ & $11.387 \mathrm{c}$ & $2.230 \mathrm{a}$ & $0.524 \mathrm{ab}$ & $0.077 \mathrm{ab}$ & $0.115 \mathrm{abc}$ \\
\hline 1.5 & $7.445 \mathrm{ab}$ & $11.173 \mathrm{c}$ & $2.189 \mathrm{ab}$ & $0.411 \mathrm{~b}$ & $0.067 \mathrm{~b}$ & $0.078 \mathrm{c}$ \\
\hline LSD & 9.999 & 3.784 & 0.260 & 0.168 & 0.032 & 0.047 \\
\hline \multicolumn{7}{|l|}{ Genotype } \\
\hline IMA-2103 & 7.677 & $11.198 \mathrm{a}$ & $2.144 \mathrm{a}$ & $0.448 \mathrm{a}$ & 0.0823 & $0.073 \mathrm{a}$ \\
\hline IMA-4409 & 7.973 & $16.601 \mathrm{~b}$ & $2.282 \mathrm{~b}$ & $0.622 \mathrm{~b}$ & 0.0888 & $0.165 \mathrm{~b}$ \\
\hline LSD & 0.394 & 1.492 & 0.102 & 0.664 & 0.013 & 0.018 \\
\hline \multicolumn{7}{|l|}{$P S$} \\
\hline I & 7.954 & $12.038 \mathrm{a}$ & $2.112 \mathrm{a}$ & 0.567 & $0.0769 \mathrm{a}$ & $0.988 \mathrm{a}$ \\
\hline II & 7.700 & $15.838 \mathrm{~b}$ & $2.317 \mathrm{~b}$ & 0.506 & $0.0944 \mathrm{~b}$ & $0.140 \mathrm{~b}$ \\
\hline LSD & 0.394 & 1.492 & 0.102 & 0.664 & 0.013 & 0.018 \\
\hline
\end{tabular}

Note. $\mathrm{CV}=$ Coefficient of variation; $\mathrm{LSD}=$ Least Significant Difference; ns $=$ not significant; $*$ significant at $5 \%$; ** significant at $1 \%$; *** significant at $0.1 \%$. Equal letters in the column represent equal means by the Tukey test at $5 \%$ of significance.

The value of soil density considered critical to root growth was $1.3 \mathrm{~g} \mathrm{~cm}^{-3}$. That is because, as in the other parameters evaluated, it presented a significant reduction when compared with the initial densities. Paludo et al. (2018) also found a similar result, in which the soil density of $1.2 \mathrm{~g} \mathrm{~cm}^{-3}$ had a negative influence on the development and growth of safflower genotypes.

Figure 2 shows the linear adjustments for each parameter that had density interference according to each genotype. In general, the angular coefficients are all in negative values, which indicates that the slope of the lines is decreasing and that the reduction of parameter variables occurs with the increase of the density. In addition, it is observed that most IMA-2103 genotype values are lower than those of the IMA-4409 genotype, a statement that is confirmed by the mean values among the genotypes presented in Table 4. 
A.

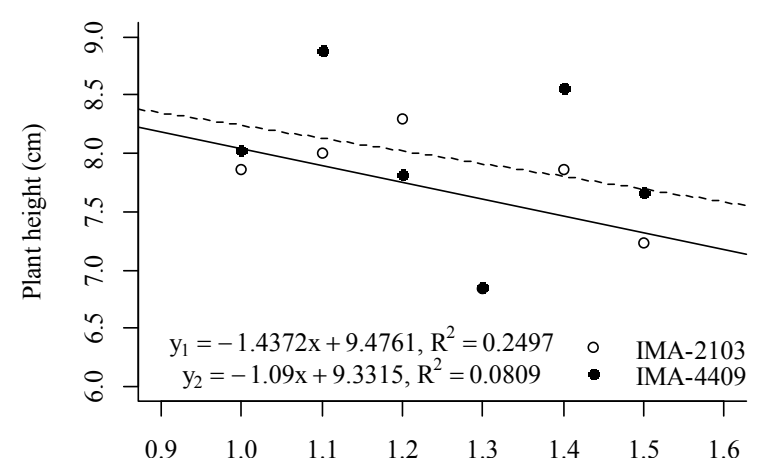

C.

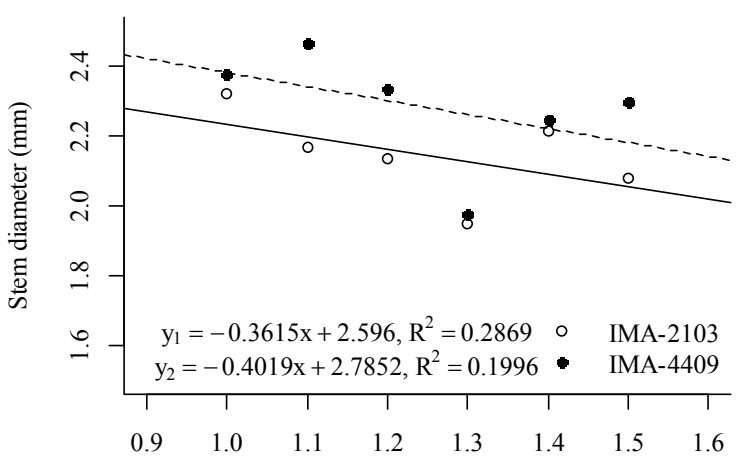

E.

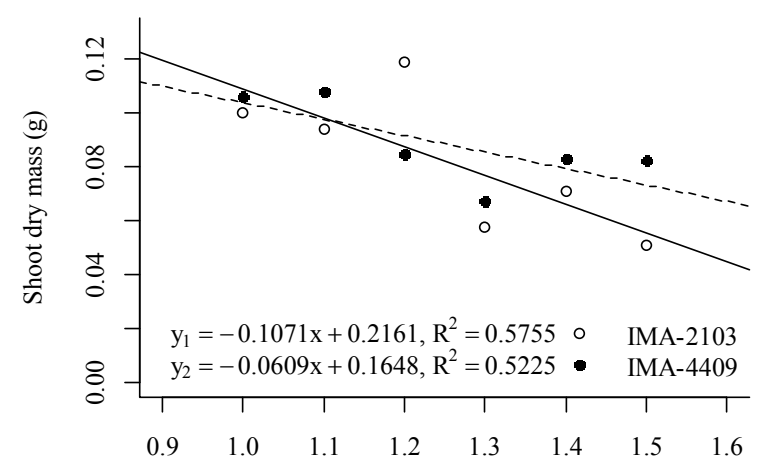

B.

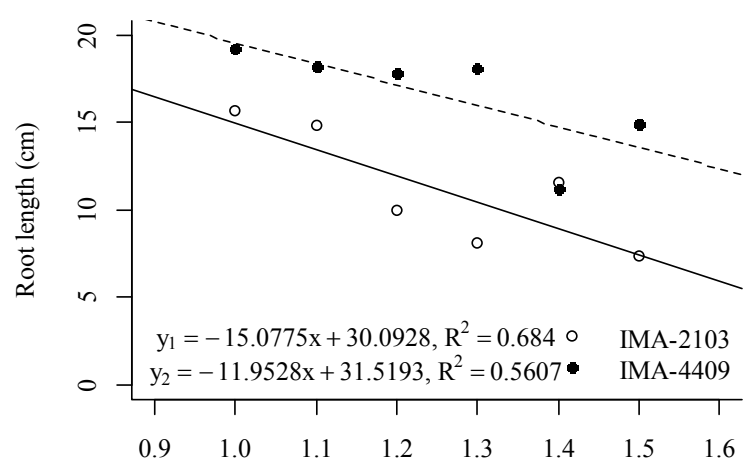

D.

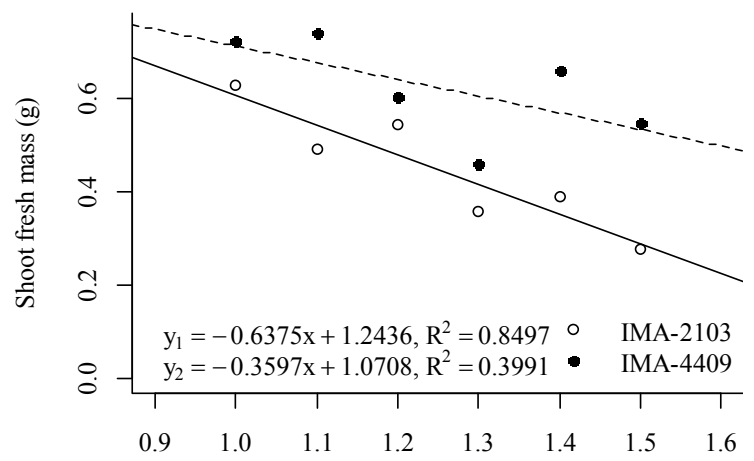

F.

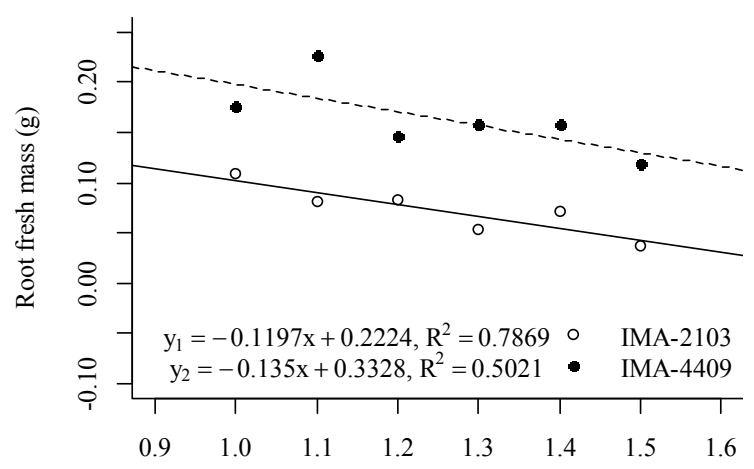

Density $\left(\mathrm{g} \mathrm{cm}^{-3}\right)$

Figure 2. Ratio between soil density and (A) plant height, (B) root length, (C) stem diameter, (D) shoot fresh mass, (E) shoot dry mass and (F) root fresh mass through two safflower genotypes

As seen in Figure 2A, it was not possible to conclude if there was a reduction of height with the increment of density. Since the coefficient of determination was low for the linear adjustment, the values of 0.2497 and 0.0809 for the IMA-2103 and IMA-4409 genotypes, respectively.

According to the work of Farias et al. (2013), when evaluating the influence of soil compaction on the morphological characteristics of pigeon pea (Cajanus cajan L. Mill sp.), there was a significant reduction in plant height with increasing compaction levels. Lima, Petter and Leandro (2006) also observed the influence of soil density on plant height of Pennisetum glaucum, Urochloa brizantha, Crotalaria ochroleuca, and Eleusine coracana cv. ANPG 207.

Regarding the compaction states in isolation, it was observed that increasing density values reduced root length. When comparing the density of $1.0 \mathrm{~g} \mathrm{~cm}^{-3}$ with $1.5 \mathrm{~g} \mathrm{~cm}^{-3}$, there was a reduction of $35.88 \%$. This corroborates the results found by Chen et al. (2014), who observed a reduction of Lupinus angustifolius roots with soil 
compaction. This is explained by the reduction in the volume of macropores, the subsequent increase in penetration resistance and, therefore, the reduced root development of the plants.

The difference was also evident between the two genotypes. Between IME-2103 and IME-4409, the increase was $48.25 \%$, as seen in Figure 3. The lines adjusted to the mean values of the root length according to the compaction (Figure 2B) presented an approximation from points to lines, as the coefficients of the determination were 0.684 and 0.5607 for the IMA-2103 and IMA4409 genotypes, respectively.

A.

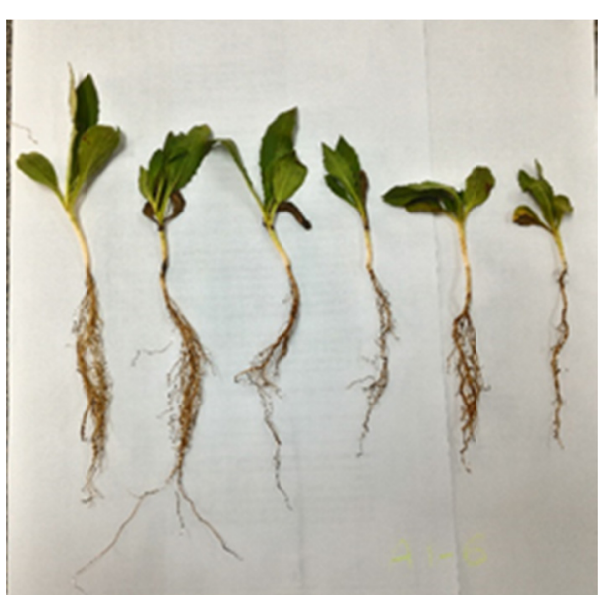

B.

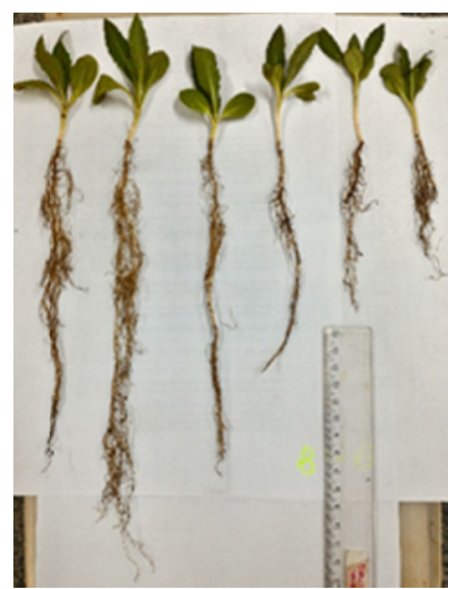

Figure 3. Two safflower genotypes sampled from PS II, with the most representative seedlings of each treatment, from left to right for treatments 1.0, 1.1, 1.2, 1.3, 1.4 and $1.5 \mathrm{~g} \mathrm{~cm}^{-3}$. (A) IMA-2103 genotype plants. (B) IMA-4409 genotype plants

A relevant consideration during the experiments in relation to the roots was their behavior in the most compacted soils (Figure 4). Due to the high penetration resistance, the roots crossed the soil layer at the sides. This is due to the contraction of the soil after the reduction of humidity, allowing an opening between the soil and the PVC wall. In addition, it was possible to view sin the central region of the layer a smaller occurrence of roots that perforated the soil. This can be explained by the high compaction state at the center of the layer, as a consequence of the accumulation of the external pressure exerted.

A.

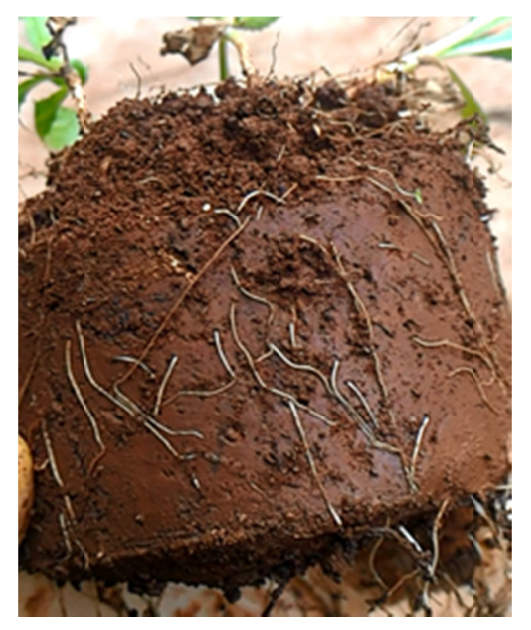

B.

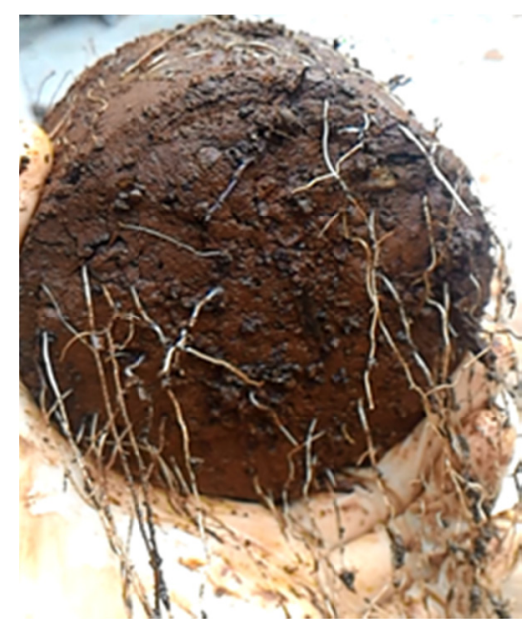

Figure 4. Compacted soil with density of $1.5 \mathrm{~g} \mathrm{~cm}^{-3}$ of IMA-4409 genotype and PS I seen from side (A) and low

(B). It should be that the roots circumvented the compacted soil on the sides and, despite perforating the compacted layer, the central region was the one with the least occurrence 
Although there was a significant difference in treatments, for the mean values of the stem diameter, there was not a considerable trend, as it presented a low representativeness to the linear adjustment. In the study of Farias et al. (2013), there was a reduction in stem diameter with the increase of soil compaction in the pigeon pea species, with a decrease of $38.49 \%$ and $41.18 \%$ for the first and second evaluation, respectively.

The shoot fresh mass presented a reduction of $38.93 \%$ from the lower density to the greater one. The IMA-2103 genotype indicated the best linear adjustment in relation to the others, with a coefficient of determination of 0.8497. Sousa, Pedrosa, Rolim, Filho and Souza (2014), when examining the initial development of sugarcane in soil compaction levels, observed that the effects of shoot fresh mass were not significant $(\mathrm{p}>0.05)$. Therefore, the reduction of the plant fresh mass with the increment of the density can be explained in relation to the decrease in root length, thereby hindering the absorption of water and nutrients from the soil.

Regarding the shoot dry mass, there was a reduction of $34.95 \%$ when comparing the less compacted soil with the most compacted one. A similar result was found by Guimarães et al. (2013), in which the millet shoot dry mass showed a $27 \%$ reduction from the lowest to the highest soil density for all genotypes analyzed. The ratios can be the same for the reduction of fresh mass with compaction. In turn, Farias et al. (2013) found a much greater reduction with the pigeon pea, i.e. $76.10 \%$, when comparing the lowest with the highest level of compaction.

With increasing density, the results showed that the root fresh mass decreased. The fresh density ratio of $1.0 \mathrm{~g}$ $\mathrm{cm}^{-3}$ had a $45.07 \%$ reduction, compared with $1.5 \mathrm{~g} \mathrm{~cm}^{-3}$. It is worth noting the significant difference between the genotypes, in which the IMA-4409 presented a mean value $126.03 \%$ higher than the IMA-2103. The linear adjustments of both genotypes showed a moderate approximation of the points on the straight lines, with 0.7869 and 0.5021 for coefficients of determination for IMA-2103 and IMA-4409, respectively. Sousa et al. (2014) did not find a significant effect in this parameter for sugarcane.

This can be evidenced by the same root length behavior, which also decreased its length with increasing density. In addition, compaction, by reducing the internal movement of water by the low volume of macropores, hinders the absorption of water by the plant, which can decrease plant fresh mass.

In Figure 2, when selecting the parameters that presented the median $\mathrm{R}^{2}$ (between 0.3991 and 0.8497 ), it was possible to verify that root length, plant fresh mass, plant dry mass and root fresh mass had their values reduced with increasing density. Table 6 shows that the IMA-4409 genotype was more tolerant to the compaction state when compared to the IMA-2103. This can be explained by the higher values of root length, stem diameter, shoot fresh mass, and root fresh mass.

Table 6. Reduction rates by the difference between the densities of 1.0 and $1.5 \mathrm{~g} \mathrm{~cm}^{-3}$ of the parameters root length (RL), plant fresh mass (SFM), plant dry mass (SDM), and root fresh mass (RFM)

\begin{tabular}{lllllll}
\hline Genotypes & RL & SFM & SDM & RFM & Mean & CV \\
\hline IMA-2103 & $52.63 \%$ & $55.78 \%$ & $48.95 \%$ & $66.48 \%$ & $55.96 \%$ & $7.55 \%$ \\
IMA-4409 & $22.24 \%$ & $24.34 \%$ & $22.36 \%$ & $32.09 \%$ & $25.26 \%$ & $4.66 \%$ \\
\hline
\end{tabular}

\section{Conclusion}

The compaction states did not significantly interfere in the emergence of safflower seedlings. As soil compaction increased, root length, shoot fresh mass, shoot dry matter and root fresh mass were reduced in both genotypes. The value of soil density considered critical to root growth was $1.3 \mathrm{~g} \mathrm{~cm}^{-3}$. The IMA-4409 genotype was the most tolerant to soil compaction compared to the IMA-2103, due to the higher values of root length, stem diameter, shoot fresh mass, and root fresh mass.

\section{References}

Ambreen, H., Kumar, S., Variath, M. T., Joshi, G., Bali, S., Agarwal, ... Goel, S. (2015). Development of genomic microsatellite markers in Carthamus tinctorius L. (Safflower) using next generation sequencing and assessment of their cross-species transferability and utility for diversity analysis. PloS ONE, 10(8), 1-22. https://doi.org/10.1371/journal.pone.0135443

Bonfim-Silva, E. M., Paludo, J. T. S., Sousa, J. V. R., Sousa, H. H. F., \& Silva, T. J. A. (2015). Development of Safflower Subjected to Nitrogen Rates in Cerrado Soil. American Journal of Plant Sciences, 6(13), 2136-2143. https://doi.org/10.4236/ajps.2015.613215 
Brás, P., Possenti, R. A., Bueno, M. S., Canova, E. B., \& Schammas, E. A. (2014). Avaliação nutricional de coprodutos da extração de óleos vegetais em dieta de ovinos. Boletim de Indústria Animal, 71(2), 160-175. https://doi.org/10.17523/bia.v71n2p160

Chen, Y. L., Palta, J., Clements, J., Buirchell, B., Siddique, ... Rengel, Z. (2014). Root architecture alteration of narrow-leafed lupin and wheat in response to soil compaction. Field Crops Research, 165, 61-70. https://doi.org/10.1016/j.fcr.2014.04.007

EMBRAPA (Empresa Brasileira De Pesquisa Agropecuária). (2006). Sistema brasileiro de classificação de solos (2nd ed.).

Fagundes, E. A., Silva, T. J., \& Bonfim-Silva, E. M. (2014). Desenvolvimento inicial de variedades de cana-de-açúcar em Latossolo submetidas a níveis de compactação do solo. Revista Brasileira de Engenharia Agricola e Ambiental-Agriambi, 18(2), 188-193. https://doi.org/10.1590/S1415-43662014 000200009

Farias, L. D. N., Bonfim-Silva, E. M., Pietro-Souza, W., Vilarinho, M. K., Silva, T. J., \& Guimarães, S. L. (2013). Características morfológicas e produtivas de feijão guandu anão cultivado em solo compactado. Revista Brasileira de Engenharia Agricola e Ambiental-Agriambi, 17(5), 497-503. https://doi.org/ 10.1590/S1415-43662013000500005

Guimarães, C. V., Assis, R. L., Simon, G. A., Pires, F. R., Ferreira, R. L., \& Santos, D.C. (2013). Desempenho de cultivares e híbridos de milheto em solo submetido a compactação. Revista Brasileira de Engenharia Agricola e Ambiental-Agriambi, 17(11), 1188-1194. https://doi.org/10.1590/S1415-43662013001100009

Labouriau, L. G., \& Valadares, M. E. B. (1976). On the germination of seeds Calotropis procera (Ait.) Ait. f. (1976). Anais da Academia Brasileira de Ciências, 45(2), 263-284.

Lima, L. B. D., Petter, F. A., \& Leandro, W. M. (2015). Desempenho de plantas de cobertura sob níveis de compactação em Latossolo Vermelho de Cerrado. Revista Brasileira de Engenharia Agricola e Ambiental-Agriambi, 19(11), 1064-1071. https://doi.org/10.1590/1807-1929/agriambi.v19n11p1064-1071

Liu, F., Guo, D. D., Tu, Y. H., Xue, Y. R., Gao, Y., \& Guo, M. L. (2016). Identification of reference genes for gene expression normalization in safflower (Carthamus tinctorius). Revista Brasileira de Farmacognosia, 25(5), 564-570. https://doi.org/10.1016/j.bjp.2016.05.006

Maguire, J. D. (1962). Speed of germination aid in selection and evaluation for seedling emergence and vigor. Crop Science, 2(2), 176-177. https://doi.org/10.2135/cropsci1962.0011183X000200020033x

Martins, E. A., Goneli, A. L., Filho, C. P. H., Mauad, M., Siqueira, V. C., \& Gonçalves, A. A. (2017). Physical properties of safflower grains. Part I: Geometric and gravimetric characteristics. Revista Brasileira de Engenharia Agrícola e Ambiental, 21(5), 344-349. https://doi.org/10.1590/1807-1929/agriambi. v21n5p344-349

Ortigara, C., Koppe, E., Luz, F. B., Kaiser, D. R., \& Silva, V. R. (2014). Uso do solo e propriedades físico-mecânicas de Latossolo Vermelho. Revista Brasileira de Ciência do Solo, 38(2), 619-626. https://doi.org/10.1590/S0100-06832014000200026

Paludo, J. T. S., Bonfim-Silva, E. M., Silva, T. J. A. da, Sousa, H. H. da F., Zanotto, M. D., \& Fenner, W. (2018). Agronomic performance of Safflower genotypes (Carthamus tinctorius L.) under different soil bulk density levels in the Oxisol of the Cerrado. Australian Journal of Crop Science, 12(3), 407-412.

R Core Team. (2014). R: A language and environment for statistical computing. R Foundation for Statistical Computing. Retrievedfrom http://www.R-project.org

Sampietro, J. A., Lopes, E. D. S., \& Reichert, J. M. (2015). Compactação causada pelo tráfego de feller buncher e skidder em um Neossolo Regolítico sob distintas umidades. Ciência Florestal, 25(1), 239-248. https://doi.org/10.5902/1980509817482

Santana, L. F., Dutra, T. D. S., Souza, M. A. D., Freitas, K. D. C., Oesterreich, S. A., Kassuya, C. A. L., \& Soares, F. L. P. (2017). Safflower Oil (Carthamus tinctorius L.) Intake Increases Total Cholesterol and LDL-cholesterol Levels in an Experimental Model of Metabolic Syndrome. International Journal of Cardiovascular Sciences, 30(6), 476-483. https://doi.org/10.5935/2359-4802.20170075

Sarto, M. V. M., Bassegio, D., Rosolem, C. A., \& Sarto, J. R. W. (2018). Safflower root and shoot growth affected by soil compaction. Bragantia, 77(2), 348-355. https://doi.org/10.1590/1678-4499.2017191 
Sharifi, R. S., Namvar, A., \& Sharifi, R. S. (2017). Grain filling and fatty acid composition of safflower fertilized with integrated nitrogen fertilizer and biofertilizers. Pesquisa Agropecuária Brasileira, 52(4), 236-243. https://doi.org/10.1590/s0100-204×2017000400003

Soleymani, A. (2017). Safflower (Carthamus tinctorius L.) seed vigor tests for the prediction of field emergence. Industrial Crops and Products, 131, 378-386. https://doi.org/10.1016/j.indcrop.2017.03.022

Sousa, C., Pedrosa, E. M., Rolim, M. M., Filho, V. P. J., \& Souza, M. A. (2014). Influência da densidade do solo infestado por nematoide no desenvolvimento inicial de cana-de-açúcar. Revista Brasileira de Engenharia Agricola e Ambiental-Agriambi, 18(5), 475-479. https://doi.org/10.1590/S1415-43662014000500002

Szymczak, D. A., Brun, E. J., Reinert, D. J., Frigotto, T., Mazzalira, C. C., Dal'col Lúcio, A., \& Marafiga, J. (2014). Compactação do solo causada por tratores florestais na colheita de Pinus taeda L. na região sudoeste do Paraná. Revista Árvore, 38(4), 641-648. https://doi.org/10.1590/S0100-67622014000400007

Toma, W., Guimarães, L. L., Brito, A. R., Santos, A. R., Cortez, F. S., Pusceddu, ... Pereira, C. D. (2014). Safflower oil: An integrated assessment of phytochemistry, antiulcerogenic activity, and rodent and environmental toxicity. Revista Brasileira de Farmacognosia, 24(5), 538-544. https://doi.org/10.1016/ j.bjp.2014.09.004

Venturoso, L. R., Bacchi, L. M. A., Gavassoni, W. L., Venturoso, L. A. C., Pontim, B. C. A., \& Reis, G. F. (2015). Inoculação de Sclerotinia sclerotiorum em sementes de oleaginosas: Transmissão e seus efeitos sobre a emergência de plantas. Ciência Rural, 45(5), 788-793. https://doi.org/10.1590/0103-8478 cr20140374

Zuo, Q., Kuai, J., Zhao, L., Hu, Z., Wu, J., \& Zhou, G. (2017). The effect of sowing depth and soil compaction on the growth and yield of rapeseed in rice straw returning field. Field Crops Research, 203, 47-54. https://doi.org/10.1016/j.fcr.2016.12.016

\section{Copyrights}

Copyright for this article is retained by the author(s), with first publication rights granted to the journal.

This is an open-access article distributed under the terms and conditions of the Creative Commons Attribution license (http://creativecommons.org/licenses/by/4.0/). 